\title{
A Prayer for Constitutional Comparativism in Eighth
}

\section{Amendment Cases}

The relevance of contemporary foreign sources to questions of constitutional interpretation is hotly debated within the Supreme Court and beyond. ${ }^{\mathrm{I}}$ It has been an issue of particular importance in the Court's recent Eighth Amendment jurisprudence where the members of a core majority have engaged in versions of constitutional comparativism when addressing the boundaries of "cruel and unusual punishment[]." This article provides a schematic argument in support of appeals to international law in Eighth Amendment cases. In particular, it contends that jurists and scholars committed to originalism ought to consider contemporary foreign sources in Eighth Amendment cases.

The Court's recent Eighth Amendment jurisprudence has been guided by three principles announced in Trop $v$. Dulles: that "the words of the Amendment are not precise," "that their scope is not static," and that the "Amendment must draw its meaning from the evolving standards of decency that mark the progress of a maturing society." ${ }^{2}$ In order to gauge this progress the Court has traditionally surveyed the practices of the several states and federal authorities, declaring unconstitutional only those practices rejected by a clear domestic consensus. ${ }^{3}$ In Atkins v. Virginia and Roper v. Simons the Court expanded the scope of its survey, consulting the practices of foreign states and transnational institutions to determine the objective decency of executing mentally retarded offenders ${ }^{4}$ and juveniles under the age of eighteen. ${ }^{5}$ In each case a vocal minority dissented both from the result and from the use of foreign sources based, inter alia, on a commitment to originalism. ${ }^{6}$

Originalists hold the view that the role of the judiciary in constitutional adjudication is to determine what the text meant at the time it was adopted. 7 This project may be advanced by consulting ancient foreign legal sources to the extent they shaped the then-contemporary objective meaning of the language. ${ }^{8}$ Modern foreign sources are irrelevant, however. Further, like evidence of framers' intent, reference to contemporary foreign sources converts the Constitution into a free-flying balloon, without objective meaning and, because subject to the creative interpretations of judges seeking to advance their own political agendas, incapable of establishing stable limits on governmental action. ${ }^{9}$

This article joins the originalist minority of the Court in rejecting claims that "cruel and unusual punishments" is not precise, that its scope is not static, and that this language must draw meaning from "the evolving standards of decency that mark the progress of a maturing society." However, it contends that originalists' refusals to consult contemporary foreign sources in Eighth Amendment cases reflect a methodological error. A closer look at the role of original meaning in Eighth Amendment analysis reveals why this is so.

Recognizing the fact of semantic drift, originalism limits the discretionary authority of appointed judges while providing stable limits on legislative and executive action by resisting the siren's song of a living constitution. ${ }^{\mathrm{IO}}$ In Eighth Amendment jurisprudence this contest has come down to one between what those living in late-eighteenthcentury America thought was cruel versus what modern Americans and fellow members of our international human rights culture regard as cruel. ${ }^{\text {II }}$ From an originalist point of view, this debate is wrongheaded.

In order to put the train back on the rails, it is essential to be rigorously faithful to the foundational commitment to original meaning. There is no doubt that moral realism was the prevailing view in the United States in I79I. ${ }^{\mathrm{I2}}$ In particular, building on Blackstone's Commentaries and the work of seventeenth- and eighteenth-century liberals, the dominant view was that justice and right in the world were a function of faith to the natural law. While there is no textual ground on which one can conclude that the Constitution incorporates the whole of the natural law, certain passages indisputably attach to objective right. The Eighth Amendment prohibition on cruel and unusual punishment is one of these.

Given that the framers and their audience were moral realists, it must be admitted that "cruel" originally meant to pick out practices that are, and always will be, cruel. ${ }^{13}$ If this is so, then it follows that judges charged with enforcing the Eighth Amendment must determine whether state conduct falls within the natural category of "cruelty." This is not the same as determining what the framers and other residents of late-eighteenth-century America thought was cruel.

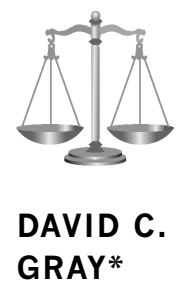

Visiting Assistant Professor, Duke University School of Law

through the University of California Press's Rights and Permissions website at www.ucpress.edu/journals/rights.htm 
While they likely had strong views on the subject, for a court to limit its inquiry to their views would give unwarranted privilege to eighteenth-century moral beliefs. If the goal is to discover original meaning, and "cruel" meant then, as it does now, to pick out an objective moral category, then it is the court's duty to discover the content of that category. Forgoing this search in favor of an inquiry into what the framers intended to capture with "cruel and unusual" either involves a category mistake or requires a move from originalism to intentionalism.

A contemporary devotee of moral realism might recognize that the framers were kindred spirits but challenge the view that unelected judges ought to engage in moral inquiry when deciding Eighth Amendment cases. ${ }^{\text {I4 Dis- }}$ agreements among committed moral realists define our times, as they have most of modern history. One might believe that well-ordered societies have a duty to resolve correctly these disputes in order to conform their practices to natural law. It does not follow, however, that unelected judges have the authority to make the call. Rather, given democratic commitments to legitimacy and collective will formation, it seems improper for judges to usurp the elected branches, which have the political authority to resolve normative contests that arise in diverse societies. ${ }^{\text {I5 }}$

From the point of view of democratic theory, there is little to dispute in the claim that the elected branches have authority to resolve contests over policy and collective conceptions of the good life and that courts must generally limit themselves to resolving disputes. Constitutional courts have a unique role, however. In constitutional democracies these bodies are charged with enforcing objective limitations on law and policy according to foundational boundaries enshrined in a constitution. ${ }^{\mathrm{I}} \mathrm{6}$

Objectivity and stability are critical to the exercise of this authority and, as originalists have pointed out, resolving constitutional disputes by reference to the natural law presents serious epistemic problems. Judges are not oracles, and any attempt by a court to reach an earnest view on what is cruel risks deteriorating into rank subjectivity. Two daunting problems follow.

First, in the face of this epistemic challenge courts have relied on "the evolving standards of decency that mark the progress of a maturing society." While some may take solace in the implied teleology, there is no warrant for a court to find the practices of contemporary institutions more humane than those of their predecessors based solely on fear of anachronism. ${ }^{17}$ Further, just as opinions on what constitutes cruelty vary between individuals (including judges), they vary over time. Thus, interpreting "cruelty" through the lens of contemporary opinion eliminates the capacity of the Constitution to act as a stable check on government action.

Second, relying on appointed judges, immune from electoral review, to decide contested normative questions is decidedly undemocratic. While there is no guarantee that the elected branches will find the right answers to questions about the content of natural law, they at least have the benefit of democratic legitimacy through electoral accountability. Further, legislative and executive opinions are reversible, whereas stare decisis may limit the capacity of future courts to correct errors by their forebears.

All of this suggests that courts ought to leave the tough moral questions to civil society, the states, and the elected branches. In most circumstances there is no sound objection to this view. In certain cases, however, the Constitution gives specific authority to the courts to resolve moral contests in order to impose moral limits on the elected branches. Eighth Amendment cases are such circumstances. In these cases, a court's refusal to decide the objective meaning of "cruelty" involves a derogation of constitutional duty and leaves the foxes to guard the henhouse.

Courts that take up this gauntlet must confront their epistemic limitations. However, if the foregoing is right, then courts deciding Eighth Amendment cases must embrace the challenge of determining the actual meaning of "cruel and unusual" rather than abdicating to eighteenth-century views. The question that remains is how. One path might be for judges to exercise their independent judgment. ${ }^{{ }^{8}}$ While faithful to originalism, such a strategy begs the fundamental questions of how a mortal judge can avoid subjectivity. Adopting an objective mode to consider scientific evidence relating to the decisional capacities of certain classes of offender or the objective utility of specific practices may solve the problem to some extent, 19 but such endeavors present their own epistemic challenges, particularly in regard to the selection and interpretation of evidence.

Another tack is to adopt an intersubjective mode. While a full argument for this position is beyond the scope of this short article, the insight is straightforward. In the absence of Platonic capacities, the best path to Truth is through substantive and open exchange with others who have an interest in the answer. This intuition underlies democratic politics and justifies truth claims by reference to a discursive process that starts in civil society and ends in law and official policy. In the few cases where determination of the moral truth is reserved for the courts, judges should incorporate a similar process into their deliberations. This task can only be achieved by consulting the same diversity of opinions and sources that would be relevant in salons and legislatures. The opinions of those foreign courts which have engaged the same issues have obvious relevance in such a pursuit. This conclusion must not be overstated. Listening does not entail deference. Foreign views on cruelty, like those of our founders, should be heard in cases addressing the constitutionality of a punitive practice, but they are only one voice in the conversation.

\section{Notes}

* J.D., New York University School of Law, 2003; Ph.D., Northwestern University, 2004.

1 Roper v. Simons, 125 S. Ct. 1183, 1206 (2005) (O'Connor, J., dissenting) and 1217, 1225.26 (2005) (Scalia, J., dissenting); Foster v. Florida, 537 U.S. 990, 991 (2002) (Thomas, J., concurring in denial of certiorari); Atkins v. Virginia, 536 U.S. 304, 
347.48 (2002) (Scalia, J., dissenting); Knight v. Florida, 528 U.S. 990, 997.98 (1999) (Breyer, J., dissenting from denial of certiorari); Printz v. United States, 521 U.S. 898, 977 (1997) (Breyer, J., dissenting); United States v. Then, 56 F.3d 464, 469 (2d Cir. 1995) (Calabresi, J., concurring); American Justice for Americans Citizens Act, H.R. 1658, 109th Cong. § 3 (2005); Constitution Restoration Act of 2004, S. 2323, 108th Cong. (2004); Hearings of Nomination of John G. Roberts as Chief Justice of the Supreme Court,: Hearing Before the Senate Judiciary Comm., 109th Cong. (Sept. 12, 2005) (exchange between then Judge Roberts and Senator Dewine) \& (Sept. 13, 2005) (exchange between then Judge Roberts and Senator Kyl); Ruth Bader-Ginsburg, Keynote Address: A Decent Respect to the Opinions of [Human]kind": The Value of a Comparative Perspective in Constitutional Adjudication, 99 Am. Soc'Y INT'L L. PROC. 351 (2005); Vincent J. Samar, Justifying the Use of International Human Rights Principles in American Constitutional Law, 37 Colum. Hum. RTs. L. Rev. 1 (2005); Diarmuid F. O'S. cannlain, What Role Should Foreign Practice and Precedent Play in the Interpretation of Domestic Law?, 80 Notre Dame L. Rev. 1893, 1907.08 (2005); Roger Alford, In Search of a Theory for Constitutional Comparativism, 52 UCLA L. REV. 639 (2005); Antonin Scalia, Keynote Address: Foreign Legal Authority in the Federal Courts, 98 Am. Soc'Y INT'L L. PRoc. 305 (2004) (hereinafter Scalia, Foreign Legal Authority); Patricia M. Wald, The Use of International Law in the American Adjudicative Process, 27 Harv. J. L. \& PuB. Pol'y 431, 441.42 (2004); Harold Koh, International Law as Part of Our Law, 98 AM. J. INT'L L. 43, 54 (2004); Daniel Bodansky, The Use of International Sources in Constitutional Opinion, 32 GA. J. INT'L \& ComP. L. 421 (2004); Stephen Breyer, Keynote Address, 97 Am. Soc'Y INT'L L. Proc. 265 (2003); Roger Alford, Federal Courts, International Tribunals, and the Continuum of Deference, 43 VA. J. OF INT'L L. 675, 793 (2003); Mattias Kumm, International Law in National Courts: The International Rule of Law and the Limits of the Internationalist Model, 44 VA. J. INT'L L. 19 (2003); Sandra Day O'Connor, Keynote Address, 96 Am. Soc'Y INT'L L. PRoc. 348, 349.50 (2002), David Fontana, Refined Comparativism in Constitutional Law, 49 UCLA L. Rev. 539, 551 (2001); Antonin Scalia, Keynote Address, American Enterprise Institute, Feb. 21, 2006 (complete video available at www.cspan.org, transcript available at http://www.aei.org/events/ filter.all,eventID.1256/transcript.asp); Association of Constitutional Law, The Constitutional Relevance of Foreign Court Decisions: A Conversation between Justice Breyer and Justice Scalia, Jan. 13, 2005 (complete video available at www.cspan.org, transcript available at http://domino. american.edu/AU/media/mediarel.nsf/0/ 1F2F7DC4757FD01E85256F890068E6E0?OpenDocument) ("Scalia-Breyer Debate"); Jeffrey Toobin, Swing Shift, THE NEW YORKER, Sept. 12, 2005, at 42.

2 Trop v. Dulles, 356 U.S. 86, 100.01 (1958).

3 See, e.g., Sanford v. Kentucky, 492 U.S. 361, 370.71 (1989) (failing to find a national consensus "sufficient to label ... cruel and unusual" the death penalty for offenders between the ages of sixteen and eighteen); Penry v. Lynbaugh, 492 U.S. 302, 334 (failing to find national consensus against executing mentally retarded offenders); Atkins v. Virginia, 536 U.S. at 314-16 (finding national consensus against execution of mentally retarded offenders); Roper v. Simons, $125 \mathrm{~S}$. Ct. at 564.68 (finding national consensus against execution of offenders under the age of eighteen).
4 Atkins, 536 U.S. at 316 n. 21.

5 Roper 125 S. Ct. at 1198-1200.

6 Id. at 1217, 1225.26 (Scalia, J., dissenting); Atkins, at 347 . 48 (Scalia, J. dissenting).

7 Originalism must be distinguished from intentionalism. Intentionalists hold the view that when judges interpret texts they should attempt to divine the intentions of its drafters. See Antonin Scalia, A Matter of Interpretation 37.41 (1997).

8 Scalia, Foreign Legal Authority, supra note 1, at 306.07; Scalia, Keynote Address, American Enterprise Institute, supra note 1; Scalia-Breyer debate, supra note 1.

9 SCALIA, supra note 7, at 40; Scalia, Foreign Legal Authority, supra note 1 , at 307.10.

10 Atkins, 536 U.S. at 311 ("A claim that punishment is exces. sive is judged not by the standards that prevailed in 1685 when Lord Jeffries presided over the "Bloody Assizes" or when the Bill of Rights was adopted, but rather by those that currently prevail."); STEPHEN BREYER, Active LIBERTY 117.118 (2005); Scalia, Foreign Legal Authority, supra note 1, at 308; Breyer, Keynote Address, American Enterprise Institute, supra note 1; Ruth Bader-Ginsburg, supra note 1, at 355 (disclaim. ing view of "the U.S. Constitution as a document essentially frozen in time as of the date of its ratification"). Etymologi. cally and historically the idea that the Constitution is a living entity traces directly to Justice Holmes's opinion in Missouri v. Holland, 252 U.S. 416, 433 (1920) ("when we are dealing with words that also are a constituent act, like the Constitution of the United States, we must realize that they have called into life a being the development of which could not have been foreseen completely by the most gifted of its begetters. It was enough for them to realize or to hope that they had created an organism; it has taken a century and has cost their successors much sweat and blood to prove that they created a nation. The case before us must be considered in the light of our whole experience and not merely in that of what was said a hundred years ago.").

11 See Roper, 125 S. Ct. at 1190-1200, 1205-17, 1217-30; Atkins, at 311.

12 ScalıA, supra note 7, at 146; Phillip A. Hamburger, Natural Rights, Natural Law, and American Constitutions, 102 YALE L.J. 907 (1993); Suzanna Sherry, The Founders' Unwritten Constitution, 54 U. CHI. L. Rev. 1127 (1987).

13 SCALIA, supra note 7, at 146. Justice Scalia goes on to suggest that "[the framers] were embedding in the Bill of Rights their moral values." This conclusion does not follow. The framers used the objective language of "cruelty." Each participant in the process of drafting and ratification may have had strong views on the content of "cruelty." However, from an originalist point of view their particular beliefs are of no moment. Then, as now, "cruel" meant cruel. Full faith to originalism requires reading the Eighth Amendment for what it actually meant rather than for the subjective beliefs its various contributors and readers might have intended to capture in the text.

14 Id.; Scalia, Keynote Address, American Enterprise Institute, supra note 1 (responding to questions from audience address. ing moral and natural law foundations of the Constitution).

15 SCALIA, supra note 7, at 9.14.

16 Jürgen Habermas, Between Facts and Norms 168.93 (1996).

17 SCALIA, supra note 7, at 44.47, 146.

18 Roper, 125 S. Ct. at 1192, 1194.98; id. at 1207 (O'Connor, J., dissenting); Atkins, 536 U.S. at 321.

19 Roper, at 1194-98; Atkins, at 317-21. 